\title{
1982 field work in the Minchumina basin, Alaska
}

Waller, S.F., and Amoco Oil Co.

GMC DATA REPORT 451

This GMC data report from the Amoco Heritage collection has been made available through funding from the FY2018 USGS National Geological and Geophysical Data Preservation Program, Grant Number G18AP00054. This project report is presented in its original format and has not been reviewed for technical content or for conformity to the editorial standards of DGGS. It should not be used or cited as reviewed data.

2019

State of Alaska

Department of Natural Resources

Division of Geological \& Geophysical Surveys

GEOLOGIC MATERIALS CENTER
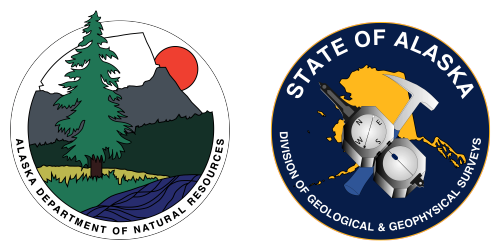


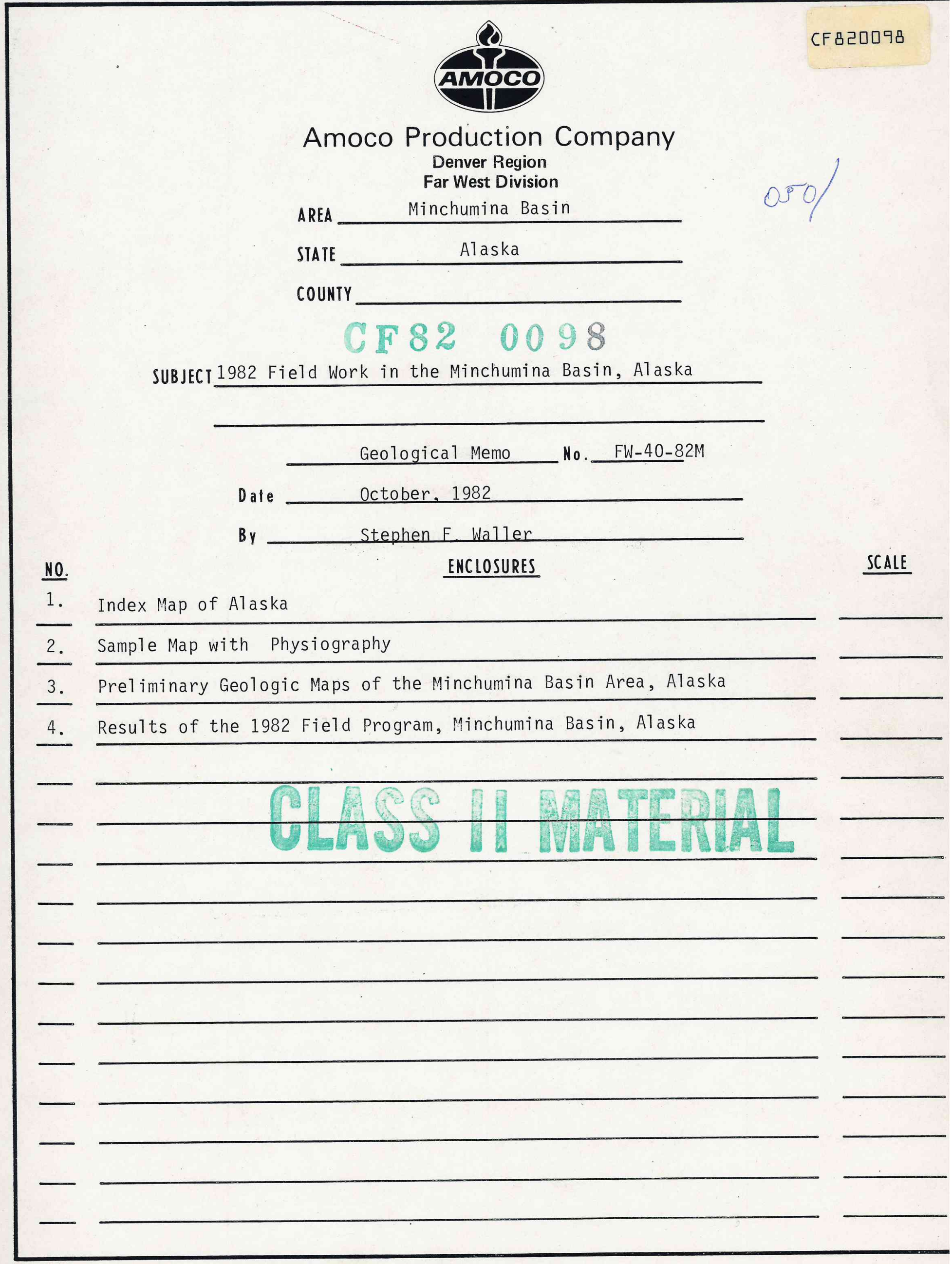


October, 1982

\author{
Far West Division \\ Geological Memoradum: \\ $\mathrm{FW}-40-82-\mathrm{M}$ \\ 1982 Field Work in \\ the Minchumina Basin, \\ Alaska
}

\title{
INTRODUCTION \\ CONCLUSIONS \\ RECOMIMENDATIONS \\ ENCLOSURES \\ DISCUSSION
}

Tertiary Nonmarine Alluvial sequence

Cretaceous Prodelta to Fluvial sequence

Paleozoic Carbonate Shelves and Tidal flats

structural Conclusions

\section{CF $82 \quad 0098$}

Author:

Stephen F. Waller 


\section{INTRODUCTION}

This brief memorandum will recount the major points and discoveries of the 1982 Interior Basins field work in the Minchumina Basin. A more comprehensive report will be completed in 1983. Fieldwork in the Minchumina Basin was undertaken to prepare Amoco for the upcoming Lime Hills Federal offering in october, 1983, and state Sale 42 in January, 1984.

The Minchumina Basin is a structural and topographic basin located north of the western Alaska Range. The Minchumina Basin is approximately 156 miles long by 42 miles wide. The Farewell (Denali) fault bounds the basin on the southeastern side, and the Nixon Fork fault bounds it on the northwestern side (See Enclosures 1 and 2). No wells have ever been drilled in the basin.

Field work in the Minchumina Basin was conducted by stephen Waller (party chief) along with Kirk Sherwood and Kipp Schrogge in the first two and a half weeks of August, and Robert Handford and Bill Jefferson in the latter one and a half weeks of August. Field work was conducted by helicopter from a base in McGrath, Alaska. The primary objectives of the field work were to:

1) Determine the hydrocarbon potential of the Cretaceous section exposed around the Minchumina Basin, including any reservoir horizons, source rock intervals, and potential seals. In addition to this, the party was to determine whether or not the cretaceous was present in the basin and to project lithologic trends of the cretaceous into the basin.

2) Evaluate the hydrocarbon potential of the Paleozoic section of the Minchumina Basin. This included identifying any reservoir horizons, source rock zones, or seals. An attempt was to be made to predict whether or not the carbonate rocks under the Minchumina Basin were deep water carbonates or shallow water carbonates.

3) Evaluate the Tertiary hydrocarbon potential of the Minchumina Basin, and predict sedimentologic trends.

All of the primary objectives were accomplished. 


\section{CONCLUSIONS}

1. There are four significant reservoir horizons that may be present in the Minchumina Basin. These are listed below, ranked in order of importance.

A. Middle(?) Cretaceous sandstones. These are predominantly lithic arenites that are tabular to cross-bedded with thin conglomeratic zones. Low-angle cross-bedded sands may range up to 2,500 feet thick and probably form a thick sheet throughout the basin. Porosity is estimated at 5 to 20 percent, based on visual inspection. Permeability was difficult to assess in outcrop, but is probably low.

B. Devonian dolomites. These are primarily vuggy, recrystalized dolomicstones, which range from 300 feet up to 1,500 feet thick. The latter thickness is somewhat conjectural, because the section is usually complexly faulted. Porosity is excellent and ranges up to $30 \%$. Permeability is probably also very good. The vuggy dolomite unit appears to be laterally extensive.

C. Devonian dolomitic wackestones. These dolomitized coralline wackestones and algal dolomicstones range up to 270 feet thick. Porosity ranges up to $25 \%$ with excellent permeabilities. The only disadvantage to this reservoir horizon is that it was only found in one section, and may be restricted by its diagenetic environment.

D. Tertiary sandstones. These sandstones were only seen in one outcrop, where they are a very immature cobble conglomerate with abundant rock fragments. The thickness ranges up to 1,000 feet thick, and porosity ranges up to $30 \%$. Permeability is probably also high. The Tertiary deposits represent graded stream and alluvial sand deposits which probably extend into the basin. The reason that this reservoir horizon is not ranked more highly is because it has no obvious seal on top of it.

2. There are two major source rock zones present in the Minchumina Basin. They are listed below, ranked in order of importance. 
A. Lower (?) Cretaceous black shales. The lower Cretaceous black to dark gray shales contain rare siltstone and sandstone interbeds which become more frequent with height in the section. It is difficult to determine the actual thickness of the Cretaceous shales because the uppermost contact with the overlying sands is not seen in outcrop. However, these shales appear to range from 400 to 3,000 feet thick, and are probably laterally extensive.

B. Silurian black limestones with some interbedded black shales. The shales are 800 to 3,000 feet thick and was probably also a laterally extensive deposit. However, these strata may be locally restricted by faults.

While source rock analyses have yet to be performed, both of the source rock horizons appear to be oil and gas sources. The Cretaceous shales appear to be thermally immature, except where they are exposed flanking igneous intrusions. The cretaceous shales are super-mature in intrusive areas. Silurian black carbonates may be thermally sub-mature to supermature; the poor exposure of the silurian means that we shall have to draw conclusions extrapolated from very sparse data.

3. Three cap rock zones were identified. These are listed below, in descending stratigraphic sequence.

A. Upper(?) Cretaceous interbedded mudstones, siltstones, coals and sandstones. This sequence is very thick, but probably only has 50 to 200 feet of a very good seal, which is predominantly sandy mudstone. The unit, as a whole, is laterally extensive. Unfortunately, it is not clear whether or not the individual mudstone/ mudshale beds or sequences are laterally extensive. It is possible that they are not, especially as the unit appears to be fluviatile. However, the mudstone should form an effective seal, even if just a thin interval is present.

B. Lower Cretaceous black shales, as described above. These shales should form an excellent seal and are laterally extensive.

C. Devonian massive micstone. The micstone ranges up to 525 feet thick, and appears to be laterally extensive. The micstones should certainly form a good seal for the underlying dolomite, 
unless extensive fracturing led to the hydrocarbons escaping. The middle Devonian micstone interval lies on top of both of the Devonian reservoir horizons described above.

4. The Cretaceous section is present south of the Nixon Fork fault, which bounds the northwestern border of the basin. No Cretaceous sections have previously been discovered immediately south of this fault. This indicates that the cretaceous is probably present in the southern part of the basin. If the Nixon Fork fault represents a tectonic boundary between two plates, then both plates must have been in place prior to the Cretaceous.

5. The Upper Cretaceous fluviatile section which consists of interbedded mudstones, siltstones, and sandstones, is present immediately west of the basin. This is important because it indicates that the Upper Cretaceous cap rock horizon may be present in the basin.

6. Shallow water Paleozoic carbonates are present within the basin. While it is possible that the pre-Devonian section in the Minchumina Basin consists of deep water carbonates, the Devonian section clearly contains shallow water carbonates.

7. No significant Paleozoic reefs occur around the Minchumina Basin. What have been previously described as reefs or waulsortian mounds (Patton, 1982, pers. comm.) are simply localized coralline biostromes.

8. The Paleozoic carbonates along the northern border of the basin are very tightly folded. The contact between the Paleozoic carbonates and the Cretaceous sands, which sometimes overlie them, is so poorly exposed that one cannot tell whether the cretaceous is folded as tightly as the carbonates. However, the cretaceous is not folded as tightly as the Paleozoics where the cretaceous is clearly exposed to the north of the Paleozoic outcrop.

9. Intrusives are present as the cores of many of the hills surrounding the basin. This may explain why previous source rock results have shown that the rocks are well past peak generation, and may also explain why some of the Cretaceous sandstones look so tight. 


\section{RECOMIMENDATIONS}

\section{Petrology}

1. Determine the level and types of diagenesis and porosity of the prospective reservoir horizons. This will involve making thin sections of pertinent samples, especially the lithic arenites, the quartz arenites, the conglomerates, the dolomites, and the dolomitic wackestones. Use feldspar stain, alizarin red, and blue porosity impregnation where appropriate. Sedimentary source area and petrographic compositions should also be determined.

2. In order to aid thin section petrographic work, bulk $x-r a y$ and oriented slide $x-r a y$ analyses of the thin section blanks should be made prior to impregnation.

3. Analyze the sedimentary structures and ichnofossils to help determine the depositional environment. Make polished slabs of most of the carbonates collected, as well as slabs of selected crossbedded sandstones.

4. Undertake an insoluable residue study of the black carbonates to determine the total organic percentage. This may be used to cross-check the source rock results.

5. Undertake a fluid inclusion study of the calcite veins in the carbonates in order to determine the temperature of formation and the salinity of the fluids.

\section{Paleontology/Palynology}

6. Analyze the shales and siltstones for the micropalentology content in order to obtain age dates and environmental control.

7. Analyze the cherts for the radiolarian and cocolith content.

8. Analyze the shales and siltstones for any spores or pollen.

\section{Stratigraphy}

9. Undertake a Markov analysis of the tidal carbonate sequences in the Paleozoic section, in order to determine if any sedimentary cycles may be seen.

10. Rotate out the regional dip from the paleocurrent measurements taken in this past field season. We should also attempt a palinspastic reconstruction of Fossil Mountain 
Syncline in order that the crossbed measurements would represent true depositional current directions.

\section{ENCLOSURES}

1. Index Map of Alaska

2. Sample Map with Physiography

3. Preliminary Geologic Maps of the Minchumina Basin Area, Alaska

4. Results of the 1982 Field Program, Minchumina Basin, Alaska

\section{DISCUSSION}

\section{TERTIARY NONMARINE ALLUVIAL SEQUENCE}

The Tertiary strata were only measured in one outcrop. This is because only one Tertiary outcrop was found to be northnorthwest of the Farewell fault. The Farewell fault is a strike-slip fault of uncertain movement, hence only sections on the basinward side of the fault might be respresentative of the Tertiary in the basin. Furthermore, Taylor and Miers (1974) have measured most of the pertinent Teritary sections in the Alaska Range in previous field seasons in the Minchumina Basin, so we have a reasonable idea of the appearence of the Tertiary across the Farewell fault. All the Tertiary sediments appear to be similar from the standpoint of a depositional environment. The Alaska Range terrain was probably accreted to the Minchumina Basin terrain prior to the Tertiary, so Taylor and Miers measured sections are probably complimentary to the most recently measured section.

The Tertiary section that is north of the Denali-Farewell fault is in $R 27 \mathrm{~W}$ and $\mathrm{T} 26 \mathrm{~N}$ to $27 \mathrm{~N}$. This section is well exposed in a steep stream cut bordering Khuchaynik Creek.

The Tertiary sediments in this southern half of the Minchumina Basin are all very coarse, immature sandstones and conglomerates. They are predominently cobble conglomerates with abundant sedimentary, metamorphic and volcanic rock fragments, which grade upward into very coarse to coarse lithic arenites. All the clasts and grains are very angular in appearance, and were probably deposited in a braided stream to alluvial fan setting - much as the sands are being deposited in the Minchumina Basin today. 
The conglomerates range up to 1,000 feet thick and were probably deposited as gentle fan-shaped deposits projecting into the basin. An aerially restricted gravity low is present immediately north of where the Tertiary outcrops occur; I feel that this gravity low may represent a very localized Tertiary sub-basin. This may mean that the Tertiary is not present as a significantly thick section elsewhere in the basin.

The Tertiary section looks very good from a reservoir standpoint. Porosities range up to $30 \%$ and the permeability is probably very good to excellent. The only problem with permeability or porosity would be if the immature, often chloritic, rock fragments are flattened with depth in the basin. This is unlikely, however, as the Tertiary is probably not buried very deeply in the Minchumina. There appears to be no obvious source intervals in the Tertiary, but minor coal beds are present throughout the section. The fact that one does not see a thicker source horizon does not mean that a lacustrine sequence could not have developed further basinward in the Tertiary, as is developed in the Tanana Basin.

The only drawback to the Tertiary section, and it is a major drawback, is that there is no apparent seal to any structure that might develop in the Tertiary. The coals are probably not thick enough to form a seal; and they are not laterally extensive enough to form an effective seal even if they were thick enough. It is possible that a lacustrine sequence might have formed in the basin, and that this might form a seal over some of the Tertiary. However, it is impossible to project or predict this within the basin at this time.

\section{CRETACEOUS PRODELTA TO FLUVIAL SEQUENCE}

The Cretaceous section may be divided into an upper "fluvial" section, a middle "bar" sandstone and siltstone section, and a lower "prodelta" shale section. The Cretaceous is exposed around the western half of the basin, but the exposures are not very good because of the friable nature of the rock. The only good exposures of the Cretaceous are present in Fossil Mountain syncline, but some other less complete exposures were measured as well. The Amoco field party was able to measure two continuous sections across Fossil Mountain; these sections appear to have contained most of the middle part of the cretaceous section. This middle part of the section contains the primary reservoir horizon, which is predominantly a cross-bedded lithic arenite. The middle part of the section, which is characterized by this lithology, may range up to about 4,000 feet thick. The lowermost section is predominately composed of dark gray to black mudstones and shales, with some interbedded silts and sands. This part of the section is easily weathered, so it is not totally exposed anywhere in 
the basin. However, some short sections are present immediately west of the Fossil Mountain syncline, and along the Kuskokwim River south of the Nixon Fork fault. The shales are also exposed in the Mystery Mountains, the Sunshine Mountains, and to the north of Page Mountain. The section through the lower Cretaceous is more complete in these areas, but it is rife with intrusives. Little time was spent perusing these examples, other than to estimate the thickness of the shales present, as the deposits were too tightly fused to tell much about the nature of the rock or the stratigraphy.

The lowermost Cretaceous mudshales and siltshales appear to be immature to mature from a thermal standpoint, and probably contain a relatively high percentage of organic debris. The shales contain some wavy, discontinuous interbeds of sandstone and siltstone throughout. Very few ichnofossils were found.

The middle part of the Cretaceous section is probably the most important. It contains continuous sand intervals, which are possibly as much as 2,000 or 3,000 feet thick. These sand intervals are predominantly lithic arenites, with some associated graywackes, quartz arenites, and conglomerates. The sands are commonly very low-angle, tabular to trough crossstratified units, which are defined by very thin mudstone laminae. Discrete sand beds, which probably represent some form of migrating sand bar, range from 2 to 30 feet thick. Porosity and permeabilty zones probably vary greatly throughout these beds because of the cross stratification. The porosity in outcrop did not appear to be too good, but porosity estimation difficulties were compounded by all the lichens covering the rocks. Fortunately, the thick pay horizon might overshadow porosity deficiencies that these rocks might have. It is also possibile that porosity might be enhanced in the subsurface because of diagenesis of the lithic fragments.

The precise depositional environment of these sands, while postulated to be bars, is very difficult to determine. This is because the muddier sequences in the section were completely covered, and there is no method of determining what sedimentary structures are incorporated in these fine-grained deposits. By digging into the hillside, we could determine that most of these covered sequences were either graywacke, siltstone, or silty mudstone to silty mudshale. None of these rocks appear to be very effective source rocks; this means that the source for the Cretaceous sands must come from the underlying dark gray shales.

The thick middle Cretaceous sands and the lower Cretaceous shales appear to be overlain by an upper cretaceous fluvial sequence. Unfortunately, this cannot be positively ascertained, because the best exposure of this sequence, which is 
along the selatna River in the south part of the basin, does not show the underlying sequence. However, one may assume that this fluvial sequence is on top of the section because some fluvial influences may be seen near the top of the section in Fossil Mountain syncline. In Fossil Mountain syncline, the massive, tabular, cross-sets grade up into finely interbedded conglomerates, mudstones, very finely cross-laminated sandstones and siltstones, and rare coals. It is possible that more coals are present, because most of the softer strata are covered.

Patton et al. (1980) agrees with the conclusion that the Cretaceous is capped by this nonmarine sequence; indeed, the U.S.G.S. felt that the top of the sequence represented an alluvial fan. Their reasoning for an alluvial fan is probably because of the presence of conglomerates at the crest of Fossil Mountain syncline. Actually, these conglomerates are present as very thin beds throughout the section, and are not a reflection of a simplistic shallowing-upwards in the sequence. In addition to this, the conglomerates don't show the grading or the thickness that one would expect from an alluvial fan sequence. However, it is our opinion that the conglomerates' more common appearance in the upper part of the section indicates a greater fluvial influence.

The fluvial sequence in the selatna River area is dominated by sands, and contains very little mud. It is difficult to distinquish the marine from the nonmarine portions of the Cretaceous because of this lack of mud in the sedimentary system. The lack of clay or mud was probably because the Minchumina area was such an immature sedimentary province during the Cretaceous. However, the uppermost part of the Cretaceous appears to contain many fining-upwards sequences in the sands, which are probably point bar deposits. This part of the section also contains many more conglomerates and coals than the lower and middle parts of the section. The coals presumably formed in a nonmarine marshy setting, possibly as flood plain deposits.

\section{PALEOZOIC CARBONATE SHELVES AND TIDAL FLATS}

The Paleozoic carbonates of the Minchumina basin appear to be nonprospective upon an initial reconnaissance. The vast majority of the carbonates exposed in the Minchumina basin are thickly to thinly bedded micstones, without any distinguishing sedimentary structures or allochems. The rocks are highly indurated, and give no evidence of any porosity or permeability. In addition to this, all of the Paleozoic carbonates are sharply folded and are intruded in certain places. In the past, geologists have looked at the carbonates in the areas where they are associated with these intrusives, and have erroneously 
concluded that most of the paleozoic carbonates are recrystallized. However, the recrystallization of the micstones is quite localized and is controlled by the intrusives. The Paleozoic of the Minchumina Basin has been heralded by the U.S.G.S. as prospective, because it contains many vuggy dolomite intervals. These intervals were all reported to be prospective, in addition to the shelf carbonates, which were supposed to contain both bioherms and reef buildups. The Paleozoic was also purported to contain a thick section of Wenlockian (silurian) black shales.

Many of the reports on the Paleozoic carbonates are not quite true. There are no true reefs or carbonate mounds. There are numerous dolomitic intervals throughout the Paleozoic, but only one interval has significant vuggy porosity; this interval is described below. Black shales are present, but they are quite rare and were only found in one locality. This is because of the following two reasons: the silurian is only exposed in one part of the outcrop belt because of faulting, and also because the silurian is predominantly a black micstone, and not a true shale.

The lack of reefs or organic buildups was disappointing. The areas that were purported to contain reefs were examined, and the deposits that were described as such were found. The place where the reefs were said to occur is along the Brown's Fork Creek, on a very long northeast-southwest trending hill. The "reefs" described by the U.S.G.S. were exposed on the northwest side of this elongate ridge. This locational information was obtained first-hand, as the result of a phone call placed to the U.S.G.S. The "reefs" are only localized coralline biostromes; most of the corals were colonial corals which showed no evidence of any sort of carbonate build-up or framework.

The other area where carbonate buildups were supposed to occur is in the upper silurian section, which is present southeast of Whirlwind Creek. This entire section was measured, and none of the Favosites bioherms that are reported in the literature were found. Favosites are present in biostromes, but they are sparse. None of the coralline zones are thicker than three to five feet, and they are poorly bedded deposits.

However, there are two intervals in the Paleozoic carbonates that are of great interest from a reservoir standpoint. Primary among these is a very thick, vuggy, recrystallized dolomite sequence exposed to the south of Whirlwind Creek. The vuggy porosity in this sequence is spectacular; porosities consistently range up to $30 \%$. Permeability is probably excellent. The only difficulty is in assessing the thickness of these rocks. The section is beset by numerous faults, so that one 
cannot discern true stratigraphic thickness for any of the sections that were surveyed. The vuggy dolomite does appear to be areally extensive, however. The dolomite is traceable in outcrop from whirlwind creek near the south end of the carbonate outcrop belt, all the way up into the sischu Mountains. The vuggy dolomite appears to be restricted only by faults, and not by any diagenetic boundaries. This could, of course, change in the basin.

The other prospective part of the Paleozoic section is a partially dolomitized wackestone to micstone found south of Whirlwind creek. This interval is not very well exposed, but it is over $100 \mathrm{ft}$ thick. Porosity is primarily intercrystalline with some inter- and intrapartical porosity also present. Permeability appears to be very good to excellent.

The dolomitic wackestone unit may have even more effective porosity than the vuggy dolomite, but the sequence was only found in one locality. Of course, this unit may be present elsewhere and was just missed in outcrop. Another possibility is that the original wackestone and micstone sequence is present elsewhere in outcrop, but it is not partially dolomitized or recrystallized to the point where it displays this good porosity. The third possibilty is that the unit is simply not exposed elsewhere due to the complex faulted and folded nature of the Paleozoic rocks. This latter scenerio seems quite possible, as there are many other distinctive units in the carbonates, such as the biostromes, which were only seen in one locale.

Another important aspect that was learned about the Paleozoic carbonates, is that shallow water carbonates are present in the southern part of the Minchumina basin. Prior to this field survey, Paleozoic carbonates in the Minchumina basin were all thought to be deep water carbonates. This conclusion resulted from the U.S.G.S. having measured a deep water carbonate section at Lake Minchumina in the north part of the basin, and also having noted that most of the Paleozoic section in the northeastern part of the basin is composed of deep water massive chert deposits. It was presumed that these carbonate deposits were indicative of what was present under the basin. However, the Amoco field party was able to look at carbonates north of the Farewell Fault at st. John's Hill and in the White Mountains. St. John's Hill is totally composed of bioclastic coralline wackestone to packstone shelf sediments. Some of the featureless micstones in the lower part of the White Mountain Measured section are possibly deep water carbonates, but certainly the upper parts of the section are not deep water carbonates at all. The upper part of the section is comprised predominantly of sparsely fossiliferous wackestones and dolomites. 


\section{STRUCTURAL CONCLUSIONS}

The major structural contribution of this field study was the conclusion that the cretaceous is present south of the IditarodNixon Fork Fault. This can be said with some certainty, because the field party measured lower cretaceous shales immediately south of the fault bordering the north side of the basin. The field party also found Cretaceous in the Kuskokwim Hills bordering the western part of the basin.

It is still possible that the cretaceous is not widely present throughout the basin. This is because the Nixon Fork Fault undoubtedly has some large faults paralleling the main fault; on the south side. This hypothesis is supported by the presence of many northeast/southwest faults that cut through the Paleozoic carbonates. It is possible that the cretaceous south of the Nixon Fork Fault is merely due to a minor fault bringing it to the surface or preserving it in some way. However, to conclude that this is true seems overly speculative at this time. We can positively conclude that the Nixon Fork Fault is not a tectonic boundary, or at least was not in Cretaceous time. We see the exact same upper Cretaceous sequence in the Kuskokwim Hills bordering the Minchumina Basin south of the fault as we do in Fossil Mountain syncline, which is north of the Fault. From what we have seen of the Paleozoics in the south side of the Minchumina Basin, the Nixon Fork Fault was probably not a tectonic boundary during Paleozoic time either, judging from the similarity betweeen the Paleozoic carbonates north and south of the fault. However, the Paleozoic carbonates do not correlate across the Nixon Fork Fault nearly as well as the Cretaceous does.

Another important conclusion is that many of the hills to the west of the Minchumina Basin, as well as to the north, are cored by intrusives. This may partially explain why previous field parties have given such a poor report on the Cretaceous potential. The hills that are cored by the intrusives are more highly indurated, and therefore are more resistant to erosion. The hardened Cretaceous sands around the intrusives are generally less highly vegetated than the unaltered sandstones, and hence are more easily sampled. One needs to be very careful in this area in order to avoid selectively sampling these altered, hardened sandstones.

Intrusives may be present as gravity highs in the basin. Fortunately, most of the intrusives that are in the area appear to be reflected by surficial topography. Luck Mountain and Lone Mountain, which represent the only areas of moderately high relief in the southern end of the Minchumina basin, are 
both reflections of intrusives that are present at their cores. I feel that the lack of any other such hills, within the basin proper, is a reflection of a lack of significant intrusives.

The last structural item which is worthy of note is the highly folded nature of the Paleozoic rocks. Many of the folds are nearly isoclinal to the north of the basin. These folds are probably related to the Nixon Fork Fault system, because these isoclinal folds were only found in association with this fault system. While the very sharp folds may be related to the major fault systems, almost all of the rocks in the Minchumina. Basin appear to be folded. The Cretaceous as found in Fossil Mountain syncline and to the west of the basin, exhibits very broad shallow folds; the Paleozoic appears to be more sharply folded throughout. The field party looked at the cretaceous where it was mapped as being in contact with the underlying Paleozoics, to determine whether the degree of folding was different in the same locale. Unfortunately, the cretaceous is so poorly exposed in these areas, that it is impossible to determine the true dip of any of the beds, both underlying and overlying. 